\title{
PERJANJIAN NEGARA-NEGARA ASEAN DALAM PEMBENTUKAN KAWASAN PERDAGANGAN BEBAS ASEAN (ASEAN FREE TRADE AREA)
}

\author{
Sobar Sukmana \\ Fakultas Hukum Universitas Pakuan, \\ Jalan Pakuan No. 1 Bogor 16143 \\ Sobar_sukmana@yahoo.com
}

Naskah diterima : 01/03/2019, revisi : 11/06/2018, disetujui 14/06/2019

\begin{abstract}
ABSTRAK
Kawasan Perdagangan Bebas Asean (Asean Free Trade Area) sudah menjadi keputusan dan ketetapan yang harus dihadapi semua negara Asean. Dengan adanya bea masuk impor barang $0 \%$, maka harga produk menjadi kompetitif di tingkat konsumen antar negara anggota Asean. Perlu adanya sosialisasi yang terus menerus dan berkesinambungan, sinergitas seluruh elemen bangsa terutama pemerintah dan para pelaku usaha harus selalu terjalin, Pada akhirnya bukan hanya para pelaku usaha baik besar, menengah maupun kecil yang merasakan langsung atmosfer persaingan usaha termasuk masyarakat umum selaku konsumen tentunya menginginkan agar pelaku usaha Indonesia dapat memenangkan persaingan sehingga Indonesia tidak menjadi "surganya" barang-barang impor. Indonesia dengan potensi sumber daya alam yang melimpah dengan jumlah penduduk terbesar di Asean merupakan modal awal untuk memenangkan persaingan. Tidak ada lagi kata tidak siap, semua harus siap.

Kata kunci : ASEAN, perdagangan bebas, AFTA.
\end{abstract}

\section{A. Pendahuluan}

Untuk mempertahankan kepentingan ekonomi di tengah-tengah era globalisasi, yang diikuti peningkatan jumlah maupun aktivitas perusahaan multinasional atau perusahaan transnasional, negara-negara sekawasan membentuk blok-blok ekonomi. Pengelompokkan negara dalam bentuk pasar bersama atau wilayah perdagangan bebas mengalami peningkatan. Hukum Internasional yang merupakan hukum yang memberi fasilitas, atau yang mengatur hubungan politik, hubungan ekonomi dan hubungan manusia yang lain, yang melintasi batas-batas negara, 
dituntut untuk berkembang dalam mengatur perkembangan-perkembangan baru yang terjadi di tengah-tengah masyarakat internasional tersebut. ${ }^{1}$

Hukum perjanjian internasional dewasa ini telah mengalami pergeseran yang radikal seiring dengan perkembangan hukum internasional. Hubungan internasional akibat globalisasi telah ditandai dengan perubahan-perubahan mendasar, antara lain munculnya subyek-subyek baru non negara disertai dengan meningkatnya interaksi yang intensif antara subyek-subyek baru tersebut.

Perubahan mendasar tersebut bersamaan dengan karakter pergaulan internasional yang semakin tidak mengenal batas negara, berpeluang untuk melahirkan perkara-perkara hukum yang bersifat lintas negara. Indonesia tidak terlepas dari perubahan mendasar ini dan bahkan juga mengalami proses tekanan dari dalam negeri, yaitu adanya tuntutan kepastian hukum di segala bidang termasuk kepastian hukum tentang hubungan antara hukum nasional dengan hukum internasional serta penerapan hukum internasional dalam pengadilan nasional.

Globalisasi di bidang perdagangan dan investasi serta lahirnya pasar bebas telah melahirkan pula pola hubungan yang lintas batas yang mengharuskan adanya pemahaman terhadap hukum perjanjian internasional.Perjanjian-perjanjian dewasa ini khususnya di bidang ekonomi, investasi dan perdagangan telah banyak menyentuh bukan hanya kepentingan negara sebagai pihak perjanjian melainkan juga melahirkan hak dan kewajiban terhadap individu-individu di negara pihak. ${ }^{2}$

Keberadaan blok perdagangan/trade block diawali dengan pembentukan Masyarakat Eropa/European Community (EC), bermula dari kerjasama di bidang batu bara dan besi baja, yang dinilai cukup berhasil kemudian meningkat menjadi perdagangan bebas di antara negara anggota, meningkat lagi tidak hanya bebas perdagangan barang tetapi juga bebas perpindahan faktor produksi sehingga menjelma menjadi satu pasar tunggal. Jangkauan lebih jauh lagi yakni menjadi

\footnotetext{
${ }^{1}$ Mohammad Burhan Tsani, "Peta Perkembangan dan Paradigma Baru Hukum Internasional". (Makalah disampaikan dalam Temu IImiah Nasional Mahasiswa Hukum, Yogyakarta 1992), hal 1.

2 Damos Dumoli Agusman, Hukum Perjanjian Internasional, Kajian Teori dan Praktik di Indonesia, cetakan kedua (Bandung, PT.Refika Aditama), hal 2-3.
} 
integrasi penuh dengan satu mata uang (European Currency Unit) serta satu Bank Sentral.

Upaya pembentukan blok perdagangan ini diikuti oleh Amerika Serikat yang membentuk Perdagangan Bebas dengan Kanada dan Meksiko, yaitu North American Free Trade Agreement (NAFTA), perdagangan bebas ini meliputi penurunan tarif, penghapusan kuota impor hasil pertanian, energi, jasa-jasa dan hak paten. Gerakan kedua blok perdagangan ini diikuti oleh Negara-negara Asean untuk membentuk blok perdagangan serupa. ${ }^{3}$

Kawasan Perdagangan Bebas Asean (Asean Free Trade Area/AFTA) merupakan wujud dari kesepakatan negara-negara asean untuk membentuk suatu kawasan perdagangan bebas dalam rangka meningkatkan daya saing ekonomi kawasan regional Asean dengan menjadikan Asean sebagai basis produksi dunia serta menciptakan pasar regional bagi sekitar 500 juta penduduknya. Kawasan Perdagangan Bebas Asean dibentuk pada waktu Konferensi Tingkat Tinggi (KTT) Asean ke 4 di Singapura tahun 1992. Ketika persetujuan Kawasan Perdagangan Bebas (AFTA) resmi ditandatangani, Asean memiliki enam anggota, yaitu, Brunei, Indonesia, Malaysia, Philipina, Singapura dan Thailand. Kemudian Vietnam bergabung pada tahun 1995, Laos dan Myanmar pada tahun 1997 serta Kamboja pada tahun 1999. Kawasan Perdagangan Bebas Asean sekarang terdiri dari sepuluh negara Asean. ${ }^{4}$

Dalam rangka mewujudkan pembentukan kawasan perdagangan bebas ini, negara Asean sepakat menghapus hambatan-hambatan perdagangan secara bertahap, guna membentuk pasar yang lebih bebas di antara sesama negara anggota, yaitu penurunan tarif bea masuk atas barang-barang yang diperdagangkan, penghapusan kuota dan hambatan non tarif lainnya yang dapat membatasi arus barang impor dari sesama negara anggota Asean. Namun negara anggota Asean

\footnotetext{
${ }^{3}$ Nopirin, "Peran Pemerintah Dalam Rangka Penanggulangan Perbuatan Curang". Makalah Disampaikan Dalam Temu Wicara Nasional Penanggulangan Perbuatan Curang, (Yogyakarta 1992).

${ }^{4}$ http://pkndisma.blogspot.com/2013/03/kawasan-perdagangan-bebas-asean-afta.html, diunduh 9 Oktober 2018.
} 
masih diperkenankan untuk mengatur sendiri tarif bea masuk barang impor dari negara-negara non Asean. ${ }^{5}$

Pada Konferensi Tingkat Tinggi (KTT) Asean ke 13 di Singapura Asean mencatat sejarah baru dengan ditandatanganinya Asean Charter/Piagam Asean pada tanggal 20 November 2007. Tujuan dibentuknya Piagam Asean atau Asean Charter, antara lain: 6

1. Mempermudah kerjasama. Adanya piagam ini akan membuat negara anggota Asean lebih terikat kepada berbagai kesepakatan yang telah dibuat. Secara teoritis, piagam itu akan semakin mempermudah pula kerja sama yang dibuat Asean dengan mitra-mitra dialognya.

2. Langkah yang lebih maju. Adanya tiga rencana yang dituliskan pada piagam tersebut, yaitu lahirnya Komunitas Ekonomi Asean, Komunitas Keamanan Asean dan Komunitas Sosial Budaya Asean.

3. Pandangan Jauh ke depan. Yaitu akan memicu terealisasinya tujuan-tujuan yang sudah tersirat. Yaitu aliran barang, investasi, jasa, modal dan tenaga terampil yang relatif lebih bebas di Asean.

4. Strategis. Piagam ini dinilai strategis karena akan menjadi landasan hukum yang menjamin integrasi politik, sosial, ekonomi, budaya, keamanan, demokratisasi, perlindungan hak asasi dan pelestarian lingkungan.

\section{B. Permasalahan}

Berdasarkan latar belakang di atas, maka dapat dikemukakan dua rumusan masalah sebagai berikut :

1.Bagaimana proses pembentukan kawasan perdagangan bebas Asean (Asean Free Trade Area) ?

2. Bagaimana implementasi perjanjian kawasan perdagangan bebas Asean (Asean Free Trade Area) dalam sistem hukum nasional Indonesia?

\footnotetext{
${ }^{5}$ Bermand Hutagalung, "Memahami Kerjasama Ekonomi Perdagangan ASEAN-AFTA dengan Mitra Dagang Lainnya", Makalah, hal-5.

${ }^{6}$ http://apamengapadanbagaimana.blogspot.com/2010/03/apa-tujuan-dibentuknya-piagamasean.html, diunduh 9 oktober 2018.
} 


\section{Kajian Teoritis Perjanjian Internasional}

Vienna Convention on the Law of Treaties $1969 .^{7}$

Article 2. 1 (a) :

"Treaty" Means an international agreement concluded between states in written form and governed by international law whether embodied in a single instrument or in two or more related instruments and whatever its particular designation.

Article 2. 1(b) :

Ratification, acceptance, approval and accession mean in each case the international act so name whereby a state establishes on the international plane its consent to be bound by treaty.

UU No. 24 Tahun 2000 tentang Perjanjian Internasional. ${ }^{8}$

Pasal 1 (1) :

"Perjanjian internasional adalah perjanjian dalam bentuk dan nama tertentu yang diatur dalam hukum internasional yang dibuat secara tertulis serta menimbulkan hak dan kewajiban di bidang hukum publik."

Pasal 1 (2) :

Pengesahan adalah perbuatan hukum untuk mengikatkan diri pada suatu perjanjian internasional dalam bentuk ratifikasi (ratification), aksesi (accession), penerimaan (acceptance) dan penyetujuan (approval).

Pasal 9

(1) Pengesahan perjanjian internasional oleh pemerintah RI dilakukan sepanjang dipersyaratkan oleh perjanjian internasional tersebut.

(2) Pengesahan perjanjian internasional sebagaimana dimaksud ayat (1) dilakukan dengan Undang-undang atau Keputusan Presiden.

Pasal 10

Pengesahan perjanjian internasional dilakukan dengan UU apabila berkenaan dengan :

7 Vienna Convention on the Law of Treaties 1969.

${ }^{8}$ UURI No.24 Tahun 2000 tentang perjanjian internasional. 
a. Masalah politik, perdamaian, pertahanan dan keamanan Negara;

b. Perubahan wilayah atau penetapan batas wilayah Negara RI;

c. Kedaulatan atau hak berdaulat Negara;

d. HAM dan lingkungan hidup;

e. Pembentukan kaidah hukum baru;

f. Pinjaman dan/atau hibah luar negeri.

\section{Pasal 11}

(1) Pengesahan perjanjian internasional yang materinya tidak termasuk materi sebagaimana dimaksud Pasal 10, dilakukan dengan Keputusan Presiden;

(2) Pemerintah RI menyampaikan salinan setiap Keputusan Presiden yang mengesahkan suatu perjanjian internasional kepada DPR untuk dievaluasi.

Suatu terminologi/istilah perjanjian internasional digunakan berdasarkan permasalahan yang diatur dan dengan memperhatikan keinginan para pihak pada perjanjian tersebut dan dampak politisnya terhadap mereka.

Judul suatu perjanjian internasional dapat beragam, pengelompokkan suatu perjanjian dalam judul tertentu dimaksudkan untuk menunjukkan adanya kesamaan materi yang diatur. Selain itu penggunaan judul tertentu pada suatu perjanjian internasional juga dilakukan untuk menunjukkan bahwa materi perjanjian tersebut memiliki bobot kerjasama yang berbeda tingkatannya dengan perjanjian internasional lainnya, atau untuk menunjukkan hubungan antara perjanjian internasional tersebut dengan perjanjian-perjanjian internasional lainnya yang telah dibuat sebelumnya.

Adapun terminologi/istilah-istilah perjanjian internasional sebagai berikut :9

1. Treaties/Traktat.

Merupakan perjanjian yang paling penting dan sangat formal dalam urutan perjanjian, digunakan untuk suatu perjanjian yang materinya merupakan hal-hal yang sangat prinsip, memerlukan adanya ratifikasi/pengesahan.

\footnotetext{
${ }^{9}$ Boer Mauna, Hukum internasional, pengertian peranan dan fungsi dalam era dinamika global. (Bandung,:PT Alumni 2011) hal.89-96.
} 
Contoh : masalah perdamaian, perbatasan negara, persahabatan, ekstradisi.

2. Convention/Konvensi

Sama halnya dengan traktat, konvensi menduduki tempat paling tinggi dalam urutan perjanjian internasional. Merupakan perjanjian multilateral yang beranggotakan banyak negara, bersifat law making yaitu merumuskan kaidahkaidah hukum bagi masyarakat internasional.

Contoh : Konvensi Jenewa 1949, konvensi Wina 1961, 1963, 1969.

\section{Agreement}

Kedudukannya lebih rendah dari traktat dan konvensi. Perjanjian yang mengatur materi kerjasama di bidang ekonomi, kebudayaan, teknik dan ilmu pengetahuan.

4. Charter/Piagam.

Perangkat internasional yang digunakan seperti dalam pembentukan suatu organisasi internasional.

Contoh : Piagam PBB 1945, Piagam ASEAN 2007.

5. Protocol/Protokol.

Digunakan untuk perjanjian internasional yang materinya lebih sempit dibanding traktat atau konvensi.

\section{Protocol of Signature}

Berisikan hal-hal yang berkaitan dengan penafsiran pasal-pasal tertentu pada perjanjian dan hal-hal yang berkaitan dengan pengaturan teknik pelaksanaan perjanjian.

\subsection{Optional Protocol}

Protokol tambahan. Memberikan tambahan hak dan kewajiban selain yang diatur dalam perjanjian internasional. Umumnya memiliki karakter khusus dan memerlukan proses pengesahan yang terpisah dari perjanjian induknya. Misalnya : Protokol Tambahan Kovenan Internasional mengenai Hak-Hak Sipil dan Politik, 1996.

\subsection{Protocol Based on a Framework Treaty.}

Merupakan perangkat yang mengatur kewajiban-kewajiban khusus dalam melaksanakan perjanjian induknya. Misalnya : Hukum Lingkungan. 


\section{Declaration/Deklarasi.}

Berisikan ketentuan-ketentuan umum dimana pihak-pihak pada deklarasi tersebut berjanji untuk melakukan kebijaksanaan-kebijaksanaan tertentu dimasa yang akan datang. Deklarasi isinya ringkas dan padat serta mengenyampingkan ketentuan-ketentuan yang hanya bersifat formal seperti surat kuasa (full powers), ratifikasi, dan lain-lain.

8. Final Act

Suatu dokumen berisikan ringkasan laporan sidang dari suatu konferensi dan juga menyebutkan perjanjian-perjanjian atau konvensi-konvensi yang dihasilkan oleh konferensi tersebut. Misalnya : Final Act GATT 1994, Final Act Embodying the Results of the Uruguay Round of Multilateral Trade Negotiation 1994.

9. Agreed Minutes dan Summary Records

Adalah catatan mengenai hasil perundingan yang telah disepakati oleh pihakpihak dalam perjanjian.

10. Memorandum of Understanding (MoU)

Perjanjian yang mengatur pelaksanaan teknis operasional suatu perjanjian induk. Sepanjang materi yang diatur bersifat teknis, memorandum saling pengertian dapat berdiri sendiri dan tidak memerlukan adanya perjanjian induk.

\section{Arrangement}

Perjanjian yang mengatur pelaksanaan teknik operasional suatu perjanjian induk.

\section{Exchange of Notes}

Pertukaran Nota. Perjanjian ini dilakukan dengan mempertukarkan dua dokumen, yang ditandatangani oleh kedua belah pihak pada masing-masing dokumen.

\section{Process Verbal}

Mencatat pertukaran atau penyimpanan piagam pengesahan atau untuk mencatat kesepakatan hal-hal yang bersifat teknik administratif atau perubahanperubahan kecil dalam suatu persetujuan. 


\section{Modus Vivendi}

Suatu perjanjian yang besifat sementara dengan maksud akan diganti dengan pengaturan yang tetap dan terperinci. Dibuat dengan cara tidak resmi dan tidak memerlukan pengesahan.

Anzilotti berpendapat bahwa kekuatan mengikat dari traktat (perjanjian internasional) terletak pada Adagium Latin yaitu "Pacta Sunt Servanda", yang berarti negara-negara harus melaksanakan dengan itikad baik segala kewajiban mereka dalam traktat tersebut. Apabila suatu negara telah mengikatkan diri kepada suatu traktat, maka ia tidak boleh menarik diri secara sepihak dari kewajibankewajibannya tanpa persetujuan negara-negara peserta lainnya.

Bentuk-bentuk yang utama dari traktat (perjanjian internasional) adalah sebagai berikut: 10

a. Bentuk yang digunakan Kepala-kepala Negara

Dalam hal ini traktat dirancang sebagai suatu persetujuan di antara Kepalakepala Negara.

b. Bentuk antar pemerintah

Traktat seperti ini dirancang sebagai suatu persetujuan di antara para pemerintah. Bentuk ini biasanya digunakan untuk persetujuan-persetujuan yang bersifat teknis dan non politis.

c. Bentuk antar Negara

Traktat seperti ini dirancang secara tegas atau tersirat sebagai suatu persetujuan di antara negara-negara. Oleh karena itu para penandatangan seringkali disebut sebagai para pihak.

d. Traktat dapat dirundingkan dan ditandatangani oleh para menteri dari setiap negara peserta, pada umumnya oleh menteri-menteri luar negeri.

e. Traktat dapat merupakan suatu persetujuan antar departemen yang ditandatangani oleh para wakil departemen pemerintah.

${ }^{10}$ J.G.Starke, Pengantar Hukum Internasional 2. Cet-1 edisi 9 (Jakarta : Aksara Persada Indonesia, 1989), hal.125. 
f. Traktat dapat diadakan diantara para tokoh politik dari negara-negara peserta.

\section{Pembentukan Kawasan Perdagangan Bebas Asean}

Konferensi Tingkat Tinggi (KTT) Asean ke IV yang diselenggarakan di Singapura pada tanggal 27-28 Januari 1992, setelah didahului oleh serangkaian pertemuan di tingkat Pejabat Tinggi dan Tingkat Menteri.

KTT tersebut membahas berbagai masalah yang mencakup perkembangan regional dan internasional yang sedang terjadi dan perkembangan kerjasama internal Asean selama ini. KTT juga membahas berbagai usulan dari negara-negara Asean baik di bidang politik, maupun ekonomi dan bidang kerjasama lain, untuk mencari bentuk dan terobosan baru dalam upaya meningkatkan kerjasama Asean.

KTT mengeluarkan tiga buah dokumen utama, yaitu :11

1. Singapore Declaration of 1992;

2. Frame Work Agreement on Enhancing ASEAN Economic Cooperation;

3. Agreement on The Common Effective Preferential Tariff (CEPT) Scheme

For The Asean Free Trade Area (AFTA).

Dokumen/Naskah pertama dan kedua tersebut disetujui dan ditandatangani oleh keenam Kepala Pemerintahan negara-negara Asean, yaitu :12

1. Sultan Brunei H. Hassanal Bolkiah;

2. Presiden Republik Indonesia Soeharto;

3. Perdana Menteri Malaysia Mahathir Bin Mohammad;

4. Presiden Philipina Corazon Aquino;

5. Perdana Menteri Singapura Goh Cok Tong;

6. Perdana Menteri Thailand Anand Panyarachun.

Sedangkan dokumen/naskah ketiga ditandatangani oleh Para Menteri Perdagangan/ Industri negara-negara ASEAN, yaitu $:^{13}$

\footnotetext{
${ }^{11}$ Departemen Perdagangan, hasil KTT Asean IV dampaknya bagi Indonesia dan langkah-langkah kongkrit untuk menghadapinya. (Jakarta Februari 1992), hal.24

${ }^{12}$ Singapore Declaration of 1992, Frame Work Agreement on Enhancing ASEAN Economic Cooperation and Agreement on The Common Effective Preferential Tariff (CEPT)
} 
1. Abdul Rahman Taib dari Brunei Darussalam;

2. Arifin M. Siregar dari Indonesia;

3. Rafidah Aziz dari Malaysia;

4. Peter D. Garrucho Jr. dari Philipina;

5. Lee Hsien Long dari Singapura;

6. Amaret Sila-on dari Thailand.

Deklarasi Singapura merupakan sebuah komitmen politik regional tingkat tinggi terhadap kesepakatan Negara-negara Asean yang telah menentukan arah dan strategi baru kerjasama asean di masa mendatang. Dengan deklarasi tersebut, Asean kini telah memiliki bekal yang lebih kuat dan pasti untuk menyongsong hari depan dan dalam menghadapi berbagai tantangan, baik internal, eksternal maupun perubahan-perubahan tata ekonomi dan politik dunia. Karena arti penting dan posisi strategis deklarasi tersebut, deklarasi Singapura juga merupakan keputusan politik yang sifatnya fundamental yang akan mempengaruhi penentuan kebijakan nasional masing-masing negara anggota. ${ }^{14}$

Frame Work Agreement on Enhancing Asean Economic Cooperation dimaksudkan sebagai payung yang sekaligus menyatukan seluruh persetujuan di bidang ekonomi, baik yang telah disetujui maupun yang akan dirancang kemudian sebagai upaya peningkatan kerjasama ekonomi yang akan datang dalam satu alur kebijakan. Persetujuan ini mencakup kerjasama dalam bidang :Perdagangan, Industri, Mineral, Komunikasi, Penelitian dan Pengembangan, Alih Teknologi, Promosi Pariwisata, Pengembangan Sumber Daya Manusia, energi dan lain-lain.

Perjanjian ini memuat arahan-arahan baru di bidang ekonomi, sebagai usaha bersama dalam upaya peningkatan kerjasama ekonomi intra Asean, yang ditujukan untuk meningkatkan pertumbuhan ekonomi dan pembangunan Asean. Keberhasilan usaha ini amat penting bagi penciptaan stabilitas dan kemakmuran kawasan.

Common Effective Preferential Tariff for ASEAN Free Trade Area (CEPT for AFTA) adalah perjanjian yang bertujuan untuk membentuk kawasan perdagangan bebas di

${ }^{14}$ Departemen perdagangan, Op. Cit., hal.17. 
wilayah Asean dalam jangka waktu 15 tahun dengan memakai tarif seragam preferensi efektif Common Effective Preferential Tariff (CEPT) sebagai mekanisme utama. $^{15}$

Adapun hubungan antara ketiga dokumen/naskah tersebut adalah sebagai berikut : 16

1. Bahwa Deklarasi Singapura pada hakikatnya memuat arahan-arahan kebijakan dan program-pragram masa depan Asean, baik yang berupa penegasan kembali atas kebijakan dan program-program lama maupun yang baru, yaitu mengenai kerjasama Asean di bidang politik dan keamanan, ekonomi, fungsional, hubungan eksternal Asean serta restrukturisasi kelembagaan Asean.

2. Bahwa Frame Work Agreement on Enhancing Asean Economic Cooperation berfungsi sebagai perjanjian induk, memayungi semua upaya peningkatan kerjasama ekonomi baik intra maupun ekstra Asean, baik peningkatan skemaskema yang telah berjalan, gagasan-gagasan terobosan baru yang telah disepakati khususnya Common Effective Preferential Tariff (CEPT) menuju terbentuknya Asean Free Trade Area (AFTA) maupun gagasan-gagasan inovatif baru yang mungkin akan timbul diwaktu yang akan datang.

3. Bahwa Common Effective Preferential Tariff for Asean Free Trade Area (CEPT for AFTA) adalah merupakan manifestasi dari perjanjian tersebut di atas yaitu di bidang perdagangan, dimana Negara-negara Asean sepakat untuk membentuk Kawasan Perdagangan Bebas Asean (Asean Free Trade Area).

Bahwa ketiga Naskah/Dokumen tersebut merupakan satu kesatuan yang tidak terpisahkan dan wajib dilaksanakan oleh semua negara anggota Asean.

Dalam realisasinya, perwujudan Kawasan Perdagangan Bebas ASEAN dengan skema CEPT tersebut mengalami beberapa dinamika perkembangan, hal ini dapat dilihat dari berbagai Konferensi Tingkat Tinggi (KTT) Asean yang antara lain membahas masalah perdagangan bebas, dengan perkembangan terakhir pada Konferensi Tingkat Tinggi (KTT) Asean ke 14 di Thailand pada tahun 2009.

\footnotetext{
${ }^{15}$ K. Algamar, "Konsekwensi-konsekwensi perjanjian ekonomi as ean menuju pasar bebas". Majalah Bulanan Manajemen dan Usahawan Indonesia.No.5thn XXI, mei 1992.hal,26.

${ }^{16}$ Departemen perdagangan, Op. Cit., hal.29-30.
} 
Pada Konferensi Tingkat Tinggi (KTT) Asean ke 14 di Cha-am Thailand tanggal 26-27 Februari tahun 2009, para menteri perdagangan dari negara-negara anggota Asean menandatangani Asean Trade in Goods Agreement (ATIGA).

Asean Trade in Goods Agreement (ATIGA) adalah penyempurnaan dari skema Common Effective Preferential Tariff for Asean Free Trade Area (CEPT for AFTA) berfokus pada jadwal pengurangan dan penghapusan tarif perdagangan barang di Asean yaitu menjadi 0 \% yang merupakan langkah konkret dalam mewujudkan integrasi ekonomi yang lebih nyata melalui Asean Economic Community (AEC) yang direncanakan tercapai pada tahun 2015 terkait dengan pergerakan arus barang (free flow of goods)sebagai salah satu elemen pembentuk pasar tunggal dan basis produksi regional.

Asean Trade in Goods Agreement (ATIGA) mulai berjalan efektif sejak 17 Mei 2010 setelah diratifikasi oleh seluruh negara anggota Asean. Bahwa berlakunya Asean Trade in Goods Agreement (ATIGA) yaitu :Brunei, Indonesia, Malaysia, Philipina, Singapura dan Thailand adalah pada tahun 2010, dengan tarif bea masuk 0\%. Sedangkan Kamboja, Laos, Myanmar dan Vietnam pada tahun 2015.17

\section{E. Implementasi Perjanjian Kawasan Perdagangan Bebas Asean dalam Hukum Nasional.}

Asean Trade in Goods Agreement (ATIGA) mulai berjalan efektif sejak 17 Mei 2010 setelah diratifikasi oleh seluruh negara anggota ASEAN. Bahwa berlakunya ASEAN Trade in Goods Agreement (ATIGA) yaitu :

1. Brunei, Indonesia, Malaysia, Philipina, Singapura dan Thailand adalah pada tahun 2010, dengan tarif bea masuk 0\%;

2. Kamboja, Laos, Myanmar dan Vietnam pada tahun 2015.

Indonesia meratifikasi Asean Trade in Goods Agreement (ATIGA) dengan Peraturan Presiden Republik Indonesia No. 2 Tahun 2010 tentang Pengesahan

\footnotetext{
${ }^{17}$ http://feb.ub.ac.id/asean-consortium-on-department-of-economics-conferenceacdec.htmI\#.VEMjclduQ9V, diunduh 19 Oktober 2018
} 
Asean Trade In Goods Agreement (Pengesahan Persetujuan Perdagangan Barang Asean).

Bahwa sebagai implementasi dari ATIGA yang telah diratifikasi, pemerintah Indonesia telah mengeluaran beberapa peraturan, antara lain :

1. Peraturan Menteri Perdagangan Republik Indonesia Nomor 33/MDAG/PER/8/2010 tentang Surat Keterangan Asal (Certificate of Origin) untuk Barang Ekspor Indonesia.

2. Peraturan Menteri Perdagangan Republik Indonesia Nomor 59/MDAG/PER/12/2010 tentang Ketentuan Penerbitan Surat Keterangan Asal (Certificate of Origin) Untuk Barang Ekspor Indonesia.

3. Peraturan Menteri Keuangan Nomor 128/PMK.011/2010 tentang Penetapan Tarif Bea Masuk atas Barang Impor Dalam Rangka ASEAN Trade in Goods Agreement (ATIGA).

4. Surat Edaran Direktur Jenderal Bea dan Cukai Nomor SE-05/BC/2010 tentang Petunjuk Pelaksanaa Penelitian Dokumen Pemberitahuan Impor Barang Dalam Rangka Skema Free Trade Agreement.

5. Peraturan Menteri Keuangan Republik Indonesia Nomor 213/PMK.011/2011 tentang Penetapan Sistem Klasifikasi Barang dan Pembebanan Tarif Bea Masuk atas Barang Impor.

6. Peraturan Menteri Keuangan Republik Indonesia Nomor 208/PMK.011/2012 tentang Penetapan Tarif Bea Masuk Dalam Rangka Asean Trade in Goods Agreement (ATIGA).

7. Peraturan Menteri Keuangan Republik Indonesia Nomor 178/PMK.04/2013 tentang Pengenaan Tarif Bea Masuk dalam Skema Asean Trade in Goods Agreement (ATIGA) dengan Menggunakan Sistem Sertifikasi Mandiri (Self Sertification).

8. Peraturan Presiden Republik Indonesia No.10 Tahun 2014 tentang Pengesahan Protocol to Amend Certain Asean Economic Agreement Related to Trade in Goods (Protokol untuk Mengubah Perjanjian Ekonomi ASEAN tertentu terkait Perdagangan Barang). 


\section{F. Penutup}

Kawasan Perdagangan Bebas Asean (Asean Free Trade Area) sudah menjadi keputusan dan ketetapan yang harus dihadapi semua negara asean. Dengan adanya bea masuk impor barang $0 \%$, maka harga produk menjadi kompetitif ditingkat konsumen antar negara anggota asean. Perlu adanya sosialisasi yang terus menerus dan berkesinambungan, sinergitas seluruh elemen bangsa terutama pemerintah dan para pelaku usaha harus selalu terjalin, Pada akhirnya bukan hanya para pelaku usaha baik besar, menengah maupun kecil yang merasakan langsung atmosfer persaingan usaha termasuk masyarakat umum selaku konsumen tentunya menginginkan agar pelaku usaha Indonesia dapat memenangkan persaingan sehingga Indonesia tidak menjadi "surganya" barang-barang impor. Indonesia dengan potensi sumber daya alam yang melimpah dengan jumlah penduduk terbesar di asean merupakan modal awal untuk memenangkan persaingan. Tidak ada lagi kata tidak siap, semua harus siap. 


\section{DAFTAR PUSTAKA}

\section{A. Perjanjian-Perjanjian Internasional}

Vienna Convention on the Law of Treaties 1969.

Declaration, Singapore Declaration of 1992.

Agreement, Framework Agreement on Enhancing Asean Economic Cooperation

- on The Common Effective Preferentian Tariff (CEPT). -Asean Trade in Goods Agreement (ATIGA) 2009

\section{B. Perundang-Undangan}

Indonesia, Undang-undang No.24 tahun 2000, tentang Perjanjian Internasional.

Peraturan Presiden Republik Indonesia No.2 tahun 2010 tentang Pengesahan ASEAN Trade In Goods Agreement (Pengesahan Persetujuan Perdagangan Barang ASEAN).

, Presiden Republik Indonesia No.10 tahun 2014 tentang Pengesahan Protocol to Amend Certain ASEAN Economic Agreement Related to Trade in Goods (Protokol untuk mengubah Perjanjian Ekonomi ASEAN tertentu terkait Perdagangan Barang).

Menteri Perdagangan Republik Indonesia Nomor 33/MDAG/PER/8/2010 tentang Surat Keterangan Asal (Certificate Of Origin) untuk Barang Ekspor Indonesia.

-----------, Menteri Perdagangan Republik Indonesia Nomor 59/MDAG/PER/12/2010 Tentang Ketentuan Penerbitan Surat Keterangan Asal (Certificate of Origin) Untuk Barang Ekspor Indonesia.

-----------, Peraturan Menteri Keuangan Nomor 128/PMK011/2010 tentang Penetapan Tarif Bea Masuk Atas Barang Impor Dalam Rangka ASEAN Trade in Goods Agreement (ATIGA).

, Menteri Keuangan Republik Indonesia Nomor 213/PMK.011/2011 tentang Penetapan Sistem Klasifikasi Barang dan Pembebanan Tarif Bea Masuk Atas Barang Impor. 

----------, Menteri Keuangan Republik Indonesia Nomor 208/PMK.011/2012 tentang Penetapan Tarif Bea Masuk Dalam Rangka ASEAN Trade in Goods Agreement (ATIGA).
----------, Menteri Keuangan Republik Indonesia Nomor 178/PMK.04/2013 tentang Pengenaan Tarif Bea Masuk Dalam Skema ASEAN Trade in Goods Agreement (ATIGA) Dengan Menggunakan Sistem Setifikasi Mandiri (Self Sertification).

Surat Edaran Direktur Jendral Bea dan Cukai Nomor SE-05/BC/2010 tentang Petunjuk Pelaksanaa Penelitian Dokumen Pemberitahuan Impor Barang Dalam Ranga Skema Free Trade Agreement.

\section{Buku-Buku}

Boer Mauna Hukum internasional, pengertian peranan dan fungs dalam era dinamika global. (Bandung,:PT Alumni 2011)

Damos Dumoli Agusman, Hukum Perjanjian Internasional, kajian teori dan praktik di Indonesia, cetakan kedua (Bandung, PT.Refika Aditama),

J.G.Starke, Pengantar hukum internasional 2. Cei1 edisi9 (Jakarta : Aksara Persada Indonesia, 1989),

Depatemen Perdagangan, hasil KTT Asean IV dampaknya bagi Indonesia dan langkah-langkah kongkrit untuk menghadapinya. (Jakarta Februari 1992).

\section{Lainnya}

BermandHutagalung Makalah : Memahami Kerjasama Ekonomi Perdagangan ASEAN-AFTA dengan mitra dagang

K. Algamar, Konsekwensi-konsekwensi perjanjian ekonomi asean menuju pasar bebas. Majalah bulanan manajemen dan usahawan indoseia.No.5thn XXI, mei 1992.

Mohammad Burhan Tsani, Peta Perkembangan dan Paradigma Baru Hukum Internasional. (Makalah disampaikan dalam Temu Ilmiah Nasional Mahasiswa Hukum , Yogyakarta 1992)

Nopirin, Peran Pemerintah Dalam Rangka Penanggulangan Perbuatan Curang. Makalah Disampaikan Dalam Temu Wicara Nasional Penannggulangan Perbuatan Curang, (Yogyakarta 1992) 
http://pkndisma.blogspot.com/2013/03/kawasan-perdagangan-bebas-aseanafta.html,diunduh9 Oktober 2014

http://apamengapadanbagaimana.blogspot.com/2010/03/apa-tujuandibentuknya- piagam-asean.html, diunduh 9 Oktober 2014

http://feb.ub.ac.id/asean-consortium-on-department-of-economicsconferenceacdec.html\#.VEMjclduQ9V, diunduh 9 Oktober 2014 